\title{
Nature as Woman in Willa Cather's O Pioneers!
}

\author{
Mukti Kandel \\ Assistant Professor of English, \\ Birendra Multiple Campus, Chitwan, Nepal. \\ Email: muktikandel43705@gmail.com
}

https://doi.org/10.3126/litstud.v34i01.39532

Abstract

The present paper explores the metaphoric and symbolic meaning of feminized nature in Willa Cather's novel O Pioneers! through the perspective of ecofeminism. The reveals that the invasion of human beings into nature is related to the patriarchy, the inequality between men and women and the binary opposition of man and nature.It primarily focuses on the characters towards nature especially in two ways - the desirable peaceful nature as a virgin and the chaotic destructive nature as a witch. This paper basically analyses how nature or land in the novel is portrayed like a virgin and a witch at the same time when the Nebraska prairie is changed into agricultural farmland. The portrayal of nature or land as stubborn or unruly land in the novel reflects the negative attitude of male characters towards nature and as such their failure to understand the Nebraska prairie especially the land of Hanover. This paper concludes that the association of women and femininity with nature in environmental discourse perpetuates patriarchal traditions and domination.

Keywords: Feminized Nature, Ecology, Anthropocentric Worldview, Witchcraft

\section{Introduction}

Willa Cather's novelsdeal with the reciprocal relationship between land and human beings. Her works revolve around the transformation of nature- particularly the prairie on the Great Divide in Nebraska - into an agriculture landscape. In O Pioneers!, Alexandra Bergson approaches this process in an intuitive way, placing her faith in the wild land and tapping its wealth by gentle means rather than by conquest and domination. Because of her hard work, patience and domination, she changes the prairie into an agricultural land. Unlike her neighbours, she views herself as collaborating with the land rather than imposing her will on it. She is fully aware that her destiny and that of the land are inseparable.

The novelrevolves around the story of Alexandra Bergson, the only daughter of Swedish immigrants John Bergson and Mrs. Bergson to the Nebraska prairie. When her father dies, she uses all her good sense and her powers of imagination to fight a living for herself, her mother, and her three brothers from the wild, inhospitable land. Her three years' of efforts, 
for making the land rich and productive turns into ashes due to the hard times of three years' drought and its impact on the crops. But she is a pioneer woman with the lure of the land. She has to struggle a lot to run her farm works. The land is dry and withered, and not fit for cultivation. She faces many obstacles but never loses her hope. As a dutiful woman, she never forgets her responsibility to the land, which is entrusted to her by her dying father.

Alexandra sacrifices her youth to a life time of hard labour. The land is very rich, beautiful and dear to her. In spite of jealousy of her brothers Oscar and Lou, she goes on working on the farm in order to fulfil her father's dream. Her boyfriend Carl Linstrum is insulted and driven away by her cruel brothers. But she stays at Hanover to make the land more fertile and productive. Because of hard labour and determination, the desolate plains and hills become fertile. Sixteen years later, having a fertile land and a comfortable homestead, Alexandra looks with satisfaction on her achievement and in her youngest brother Emil's possibilities. She successfully fulfils a sense of responsibility to the land and guardianship to her orphan brothers.

Several scholars have studied this novel from various perspectives. Due to the powerful depiction of pioneer life, the novel has drawn substantial amount of critical interpretations. John Ditsky views Willa Cather's use of the land to embody history or serve as witness to human activity. In his words, in $O$ Pioneers!, Cather argues "the possibility of triumph in life by means of accepting Nature's truths as lesson guide" (398). Likewise, Robert W. Cherry in his article "Cather's Version and History" opines: "In OPioneers!, Alexandra Bergson suffers through the hard times of the 1980s, but she treats the land with love and yearning and in the early years of the century it repays her by making her one of the richest farmers on the Divide" (Murphy 236). Alexandra, the protagonist of the novel, never loses her confidence even in the crop failure. Because of continuous dedication and her deep attachment to the land, she finally succeeds and becomes one of the richest farmers on the Divide. Another critic David Laird analyses $O$ Pioneers!from gender perspective and argues:

Alexandra's intense relationship with the land is projected in strong deliberately gendered images, sometimes feminine, sometimes masculine. She perceives the land in intimate even passionate terms, drawing strength from it and, in return, giving of her spirit and imagination. (244)

Alexandra gives herself to the task of cultivating the land, understanding its rhythm and seasons and making it serve her purposes. She challenges patriarchy in various ways and proves herself as a true pioneer. 
Because of the word limitation of the intended journal, my analysis concentrates only on the target novel and a few concepts of feminized nature in the works of environmental historian Carolyn Merchant and Yi$\mathrm{Fu}$ Tuan to prove how the metaphor of feminized nature influences the characters' attitude towards the nature. In doing so, this paper offers the working definition of the term "ecofeminism" as a tool of inquiry especially borrowing the concept of Tzeporah and Gaard. Though I have tried to survey the attitude of major characters towards nature or land of Hanover in the novel, my analysis particularly concerns how the images of feminized nature influence human behavior towards nature through the perspective of ecofeminism.

\section{The Portrayal of Feminized Nature in $O$ Pioneers!}

Compared to Cather's other works, one of the most prominent features of this novel is that the land itself is personified as a protagonist and behaveslike a human.Cather devotes a large amount of description to create the personified land as an important character in each part of the novel. The first part entitled "The Wild Land" suggests the wilderness of the land which has no cultivation. The land resists the domination. However, the second part "Neighboring Fields" suggests that the wild land is transferred into the fields or farmland where some particular crops are grown and as such the land is no longer wild or untamed or virgin. Since the title of each part tells us the significance of nature or the land in the novel, the description of the landscape and nature embrace some significant implications which need to be revealed in this article.

The portrayal of the female characters' sexuality and the land of Nebraska in the novel raises the issue of marginalized position of woman and nature. Cather questions oppressive patriarchy through her eroticized, feminized landscape in the novel. Concerning the marginalized position of woman, Defrancis insists on re-examining the status of women in society throughout history: “... the Women Question was a question of selfhood, autonomy, agency, independence, and identity that challenged women's domestic roles and fueled a culture of fear as the debate attempted to situate women in the world" (1). She argues that women articulated their own responses to their suffering in different ways for centuries. Such debate is affected by time and place as well.

Environmental historian Merchant in summarizes analogy between women and nature: "women and nature have an age-old association-an affiliation that had persisted throughout culture, language, and history" (xix). Sheasserts that "in both Western and non-Western cultures, nature was traditionally feminine. In Latin and the romance languages of medieval and early modern Europe, nature was feminine noun" (xxiii). The concept of femininity of nature proves the way men have identified 
taming of nature with that of woman historically.Merchant further discusses the image of nature as female in the history of Western culture:

In western culture, nature as Eve appears in three forms. As original Eve, nature is virgin, pure, and light - land that is pristine or barren but had the potential for development. As fallen Eve, nature is disorderly and chaotic; a wilderness, wasteland, or desert requiring improvement; dark and witchlike, the victim and mouthpiece of Satan as serpent. As mother Eve, nature is an improved garden; a nurturing earth bearing fruit; a ripened ovary; maturity. (Reinventing Eden 22)

Merchant sums up human attitudes to nature in the development of Western culture. She connects the development of modern society with the story of Eve to depict man's attitudes to woman in patriarchal culture. Her Eve in three forms mentioned above clarifies the symbolic meaning and the function of feminized nature in literary works. Many researchers are concerned with the relationship between the fear of nature with the evil of women. Tuan discusses negative imagery of nature as a bad mother or a witch in the history and argues that people strongly anthropomorphize the phenomenon of nature (107). They easily associate the chaotic power of nature with supernatural ghosts and witches on the basis of their experience and perception of nature: "Witches are a force for total chaos, and they are closely associated with other forces or manifestations of chaos such as dark nights, wild animals, wild bush country, mountains, and stormy weather" (Tuan

107).Merchant asserts that like the image of virgin land or mother nature, the chaotic and disorderly nature is related to the image of the female:"wild uncontrollable nature was associated with the female" (127). Tuan relates the chaotic nature with witches on the basis of people's perception of nature whereas the witchMerchant mentions reveal the human's underlying wish to control nature.

Dana Percec concerns ecofeminism in the specific Canadian context. She relates ecofeminism to "a narrative of national identity, women's position and the role played by nature in the collective imagination, sometimes a victim of humans, sometimes the Evil North, unyielding and dangerous" (45). The ecofeminist basically argue that women and nature should resist the pressures and prejudices of oppressive patriarchal society. Advocating the agenda of ecofeminism, Fangyuan XI in his article concludes that "the image of feminized nature represents human's attitude as well as determines their behavior to nature" (7). He asserts that analyzing and comparing the image of nature like a virgin or a witch lead us to rethink and reconsider the interrelation between human and nature. 
John Bergson's attitude towards land in the novel best expressesmen's attitude towards nature. In Chapter I, John looks back over his life and reflects on his struggle in the wilderness: "In eleven long years John Bergson had made but little impression upon the wild land he had come to tame" (11) .He becomes quite furious when he is unable to cultivate the land. He compares the wild land like a horse that no one knows break harness and that runs and kicks things to pieces. He does not have a good idea how to farm it properly in the new world. He faces lots of bitterness of nature and much troubled by harsh geography of Hanover:

A mist of fine snowflakes was curling and eddying about the cluster of low drab buildings huddled on the gray prairie, under a gray sky. The dwelling houses were set about haphazard on the tough prairie sod; some of them looked as if they had been moved in overnight, and others as if they were straying off by themselves, headed straight for the open plain. None of them had any appearance of permanence, and the howling wind below under them as well as over them. (3)

The hostile environment and the unfriendly landscape make John and the other immigrants more pathetic in their early settlement period. The nature is always hostile and unfriendly to them. Almost all of them are forced to live in sod houses and the howling wind becomes a great threat for their existence. The land in the form of drought and wind, blizzards and hail uses its weapons to resist the pioneers' determined encroachment on the divide.

John is one of the representatives of the older generation of pioneers who has the traditional belief in land: "John Bergson had the Old-World belief that land, in itself, is desirable" (12). For him, the land is desirable, and he has a strong desire to tame it. To some extent, the desirable wilderness of the American West reflects the people's fantasy of the virgin land. The pristine and barren land is pure like a virgin and as such it has the potential for development. For humans, to conquer the virgin land is to achieve their self- fulfillment. On the contrary, if the land is not conquered by men, it would be disappointing or frustrating for human: "Of all the bewildering things about a new country, the absence of human landmarks is one of the most depressing and disheartening" (11). The land reacts and resists oppression or domination. The land is disappointed and frustrated towards human intervention.

John is utterly frustrated when he fails to understand the land. He thinks the land of Hanover to be an enigma and its Genius is unfriendly to man. Like women, the land does not wish to be tamed by men. The land 
wants "to be alone, to preserve its own fierce strength, its peculiar savage kind of beauty, its uninterrupted mournfulness" (9).John fails to understand the rhythms of the prairie land. When the settlers fail to tame wild land, they become much frustrated: "The settlers sat about on the wooden sidewalks in the little town and told each other that the country was never meant for men to live in" (26). This sense of frustration of the $\mathrm{men} / \mathrm{settlers} \mathrm{proves} \mathrm{their} \mathrm{failure} \mathrm{to} \mathrm{understand} \mathrm{the} \mathrm{land.} \mathrm{Though} \mathrm{nature} \mathrm{is}$ violent and even the land is barren, men still want to explore and alter the land to satisfy their desires to conquer and possess the land. This sense of disappointment or frustration paradoxically reveals their anthropocentric attitude towards nature. John's understanding of the land of Hanover as an enigma exposes his patriarchal mindset and anthropocentric attitude to nature. The way oppressive patriarchy dominates nature, John wants to tame or control nature in the same manner. Because of this, he faces various geographical difficulties in the land of Hanover. He fails to mark the record of the plough in the wild land and dies ultimately.

John Bergson is one of the representatives of the older generation of pioneers. His attitude towards nature is equally important in the analysis of characters and their relationship to land. It is not only John who fails to understand the land of Hanover, other characters like Carl and the brothers of Alexandra do not understand the land. Alexandra's brothers utterly fail to understand the land and want to sell it. Unlike her brothers, Alexandra insists on keeping the land as she understands the strength of the land. She adapts herself to the prairie to preserve it, not to conquer it. Even Alexandra's childhood friend Carl fails to understand the importance of land and decides to settle in cities leaving Alexandra and the land of Hanover.Because of the hardships, drought and crop failure for three years, many farmers sell out their homestead plots and move away to seek their fortune in cities.

Nature is feminized as a feminine noun in the beginning of Chapter III "Winter Memory." Cather directly uses the pronoun "she" to refer to nature: "Winter has settled down over the Divide again; the season in which Nature recuperates, in which she sinks to sleep between the fruitfulness of autumn and the passion of spring" (103). Signifying nature by a feminine noun is very common in many literary works. Feminized nature is quite significant throughout this novel. In Part II, "Neighboring Fields," we find Alexandra who is able to maintain close connection with the land through agrarian farming. Unlike other male characters in the novel, she manages her land adopting co-participation with land. She can understand land better than her neighbours. She knows the land is ready for wheat while others quit putting all their land in corn. She 
successfullyleads her family against all difficulties, and constructs the beautiful garden on the wild prairie:

The Divide is now thickly populated. The rich soil yields heavy harvests; the dry, bracing climate and the smoothness of the land make labor easy for men and beasts. There are few scenes more gratifying than a spring plowing in that country, where the furrows of a single field often lie a mile in length, and the brown earth, with such a strong, clean smell, and such a power of growth and fertility in it, yields itself eagerly to the plow; rolls away from the shear, not even dimming the brightness of the metal, with a soft, deep sigh of happiness. (41)

This description of the gratifying landscape of the great harvest contains several implications. First of all, the image of the plow as an instrument appears in this scene. The plow is not only a labor instrument for pioneers but also a symbol of the invasion of civilization into the wilderness. It changes the wild land to farmland. Land or the wilderness, thus, is the rival of human beings.

The image of the plow can be found in other parts of the novel as well. In section two of Part I, the plow symbolizes human's vain effort to conquer nature: "The record of the plow was insignificant, like the feeble scratches on stone left by prehistoric races, so indeterminate that they may, after all, be only the markings of glaciers, and not a record of human strivings" (11). A series of words such as "insignificant," ffeeble" and " indeterminate" represent human's disappointment at not making a mark on the land. This passage is in a sharp contrast to the landscape in Part II which stresses man's proud plowing mark on the land. Man's proud plowing mark on the wild land or virgin land of Hanover symbolizes the notion of land ownership and conquest. Once man is able to plow the land successfully, they think land always belong to them. The plow, therefore, reflects the binary opposition between human and land, civilization and nature, man and woman. In section four of Part I, an intense conflict between them is portrayed: "Then came the hard times that brought everyone on the Divide to the brink of despair; three years of drought and crop failure, the last struggle of a wild soil against the encroaching plowshare" (26). This description of three years of drought and crop failure in the novel implies the resistance of nature against human intervention.

Despite the drought and crop failure, the gratifying harvest scene in Part II shows man's triumph over nature. The spring plowing is a gratifying scene that candles the sense of satisfaction to humans. The word "furrow" symbolizes the mark made by a plow and humans. It strengthens 
the impression of the invasion of the civilization into nature. Though the land has tremendous power in terms of its fertility, it still yields itself to the plow, and submits itself to humans. The crop field signifies man's triumph over nature.This landscape is a cultivated garden image of feminized nature, and man's triumph over nature. Since nature in Part I is different from that in Part II, "feminized nature" itself differs in each part. From John's point of view to Alexandra's one, nature transforms itself to be multi-dimensional. The stereotype of feminized nature becomes enriched especially at the hand of Alexandra who collaborates with land understanding its rhythm rather than by conquest and domination. After years of resistance, the land finally awakens to the touch of Alexandra who acknowledges and respects its being.

The sharp contrast between the two different descriptions of landscape in the novel makes the feminized nature more significant. It is necessary to compare the descriptions of land in Part I to the descriptions of land in Part II. The comparison includes two aspects: the first one is the distinction between the landscape descriptions; the second one is the difference in the characters' attitudes to nature or land. Unlike the gratifying landscape of the great harvest discussed above, the landscape in Part I is frustrating. In Part I, the Divide is described in negative attributes as a "dark country." If the gratifying landscape represents the triumph of human over nature, the image of "dark country" landscape represents human's failure to tame nature. This image of dark country or landscape is dark and horrifying. Compared to this frustrated landscape, the nature represented in Part II is bright and delightful.

Cather intentionally creates two kinds of images for nature and women: the wild and the benevolent nature. This is evident in the difference between the two female characters in the novel, the strongminded Alexandra and the emotional Marie.In Part II, Cather focuses more on the love triangle between Frank, Emil and Marie. Frank suspects his wife Marie to have fallen in love with Emil. Because of sexual jealousy, he ends up shooting them to death. The text implies that Marie is greatly responsible for this tragedy. She represents the two sides of nature as female. At first, Marie is described as a devotee and an advocate of nature. She expresses her deep attachment to nature and animals. For example, she expresses her strong love for trees to Emil: "I like trees because they seem more resigned to the way they have to live than other things do. I feel as if this tree knows everything I ever think of when I sit here" (83-84). She feels sad for the ducks which were shot by Emil. She believes that even the animals have the right to enjoy happiness and pleads Emil not to hurt the ducks again. 
From Alexandra's perspective, Marie is extremely beautiful attractive like a little brown rabbit. Her main charm comes from her love for nature. She loves nature and assimilates with it. However, at the end of the novel, she gets involved in the tragedy. Frank shoots Emil and Marie and he is sentenced to death. If Marie was not so beautiful and passionate, the tragedy would not have happened. In this respect, Marie is portrayed as a contradictory woman who is a virgin and a witch at the same time. Alexandra's description reveals Marie's destructive influence: "She blamed Marie bitterly. And why, with her happy, affectionate nature, should she have brought destruction and sorrow to all who had loved her, even to poor old Joe Tovesky" (163). At the end of the novel, Alexandra concludes the tension between the good and evil side of femininity in Marie which corresponds with the tension between the attractiveness and the destructiveness of nature: "I've seen it before. There are women who spread ruin around them through no fault of theirs, just be being too beautiful, too full of life and love. They can't help it. People come to them as people go to warm fire in winter

(167).Unlike Alexandra, Marie represents the destructiveness of nature. Marie cannot control her emotions and her love towards Emil. She is not wise and rational like Alexandra. Because of her beauty and her passionate love towards Emil, she not only ruins her life but also ruins the life of two innocent people Frank habata and Emil.

\section{Conclusion}

From John's to Alexandra's point of view, from the untamed wilderness to the cultivated nature, nature is portrayed as a multidimensional character in the novel. The novel expresses the traditional American ecological attitude to the land in two ways: the land is like a virgin that embraces the pastoral image, and the wilderness is like a witch or fallen Eve, which is chaotic, devastating and needs to be tamed and conquered by men. The tamed, improved, peaceful, and productive image of nature is the garden which the American people desire to establish. The farming tools depicted in the novel have the same symbolic and metaphorical meaning. Nature in the novel, thus, implies femininity. Throughout the novel,nature or land is not only depicted as a virgin, but also stubborn and unruly like a witch. These dichotomous depictions of feminized nature in the novel reflect men's desire to control woman as well as nature.

\section{Works Cited}

Berman, Tzeporah. "The Rape of Mother Nature? Women in the Language of Environmental Discourse.” Ed. Alwin Fill and Peter Muhlhausler. London and New York, 2001, pp. 258-269. 
Cather, Willa. O Pioneers! San Diego, CA: ICON Classics, 2005.

Defrancis, Theresa. "Women-writing-women: Three American Responses to Woman Question."Ph.D. Dissertation. University of Rhode Island, ProQuest Dissertations Publishing, 2005.

Ditsky, John. "Nature and Character in the Novels of Willa Cather."Colby Quarterly, vol. 10, no. 1, Jan. 1974, pp. 394-412.

Fangyuan, XI. "The Interpretation of Literary Images of Feminized Nature from the Perspective of Ecofeminism." The European Conference on Literature and Librarianship 2014 Official Conference Proceedings, pp. 1-8.

Gaard, Greta Claire. Ecological Politics: Ecofeminists and the Greens.Temple UP, 1998.

Laird, David. "Willa Cather's Women: Gender, Place, and Narrative in OPioneers! and My Antonia."Great Plains Quarterly, vol. 12, Fall 1992, pp. 242-253.

Merchant, Carolyn. The Death of Nature: Women, Ecology, and the ScientificRevolution, Harper San Francisco, 1980.

Merchant, Carolyn.Reinventing Eden: the Fate of Nature in Western Culture, Routledge, 1980.

Murphy, John J. Ed.Family, Community and History (The BYU Symposium), Humanities Publication Centers Provo, UTAH, 1989.

Percec, Dana. "Margaret Atwood and the Politics of Ecofeminism."ColloquiumPoliticum, vol.3, no.1, 2012, pp. 45-56.

Tuan, Yi-Fu. Landscapes of Fear. University of Minnesota Press, 1979. 